\title{
Sustainable Development and Water Resource Scarcity
}

\author{
Dave Flynn, Ph.D. \\ Professor, Hofstra University \\ Dave.Flynn@Hofstra.edu
}

\begin{abstract}
Herein, we focus on the critical relationship between climate change and sustainable development with a focus on the availability and usage of water resources, especially in China, India, and the United States. Scores of countries are over-pumping aquifers as they struggle to satisfy their growing water needs, including each of the top three grain producers-China, India, and the United States. These three, along with a number of other countries where water tables are falling, are home to more than half the world's people. After reviewing climate policy in each of these three countries, we review the depletion of water resources in each country. Finally, recommendations are made to slow the depletion of water aquifers in these countries.
\end{abstract}

\section{INTRODUCTION}

The defining issue of the twenty-first century may well be the control of water resources. While water supplies are dwindling because of groundwater depletion, waste, and pollution, demand is rising. Consumption of groundwater id increasing faster than it is naturally replenished and causing water tables to decline unremittingly (Rodell et al., 2009). Currently, 338 million people are sometimes subject to severe water shortages and by 2025 this number is projected to increase to about 3 billion (Rosegrant, 1997). In India, the water challenge is already grave and could get graver. By 2050, for instance, it is estimated that demand would go up to 1,180 million cubic metres, 1.65 times the current levels, a situation that would be made worse by fast dwindling fresh water resources (Vijayakumar, 2012).

This paper focuses on the critical relationship between climate change and sustainable development with a focus on the availability and usage of water resources, especially in China, India, and the United States. Scores of countries are over-pumping aquifers as they struggle to satisfy their growing water needs, including each of the top three grain producers-China, India, and the United States. These three, along with a number of other countries where water tables are falling, are home to more than half the world's people (Brown et al., 2012). Energy availability may limit the ability of countries to continue their economic advancement, made critically evident in the 2011 Japan earthquake and tsunami. Nuclear energy was considered their means of achieving development goals by reducing their need to import oil and coal. This and other nuclear disasters, e.g. Chernobyl and Three Mile Island, have threatened the availability of clean water. Alternatives such as natural gas hydraulic fracturing, coal mining, and off-shore oil drilling also threaten water resources (Flynn, 2011). Recommendations will be made to achieve a sustainable world economy to prevent further climate change and to increase the efficiency of water usage.

A sustainable economy must limit withdrawals from, and produce investments in all forms of capital (human, social, and natural) to ensure that no form of capital is diminished in order to increase short-term output of marketable goods and service (Lant, 2004:22). "Sustainability of human activities (predominantly production and consumption) is a growing concern among 
businesses, customers, governments, international bodies and non-governmental organizations. These concerns are often linked to energy efficiency, reduction of environmentally harmful emissions, ecosystem preservation and other conservation efforts. They are becoming a part of a "triple bottom line" for business accounting: financial, social and environmental" (Hermanowicz, 2005).

At the fifteenth United Nations Framework Convention on Climate Change (UNFCCC) in Copenhagen in December 2009, developed countries pledged to raise $\$ 100$ billion dollars over the next decade to help the developing world respond to climate change. However, according to Boder (2010), very little money has been given to the developing world. Over 100 heads of state attended the conference. However, the meeting was less than successful because of the friction between rich and poor countries. For example, the wealthy countries insisted upon verifiable cuts in emissions from major developing countries like India and China (Boder, 2010). China relies on coal for approximately 75\% of its energy needs, but it consumes twice as much energy as it generates according to the State Grid Corporation of China (see Figure \#1).

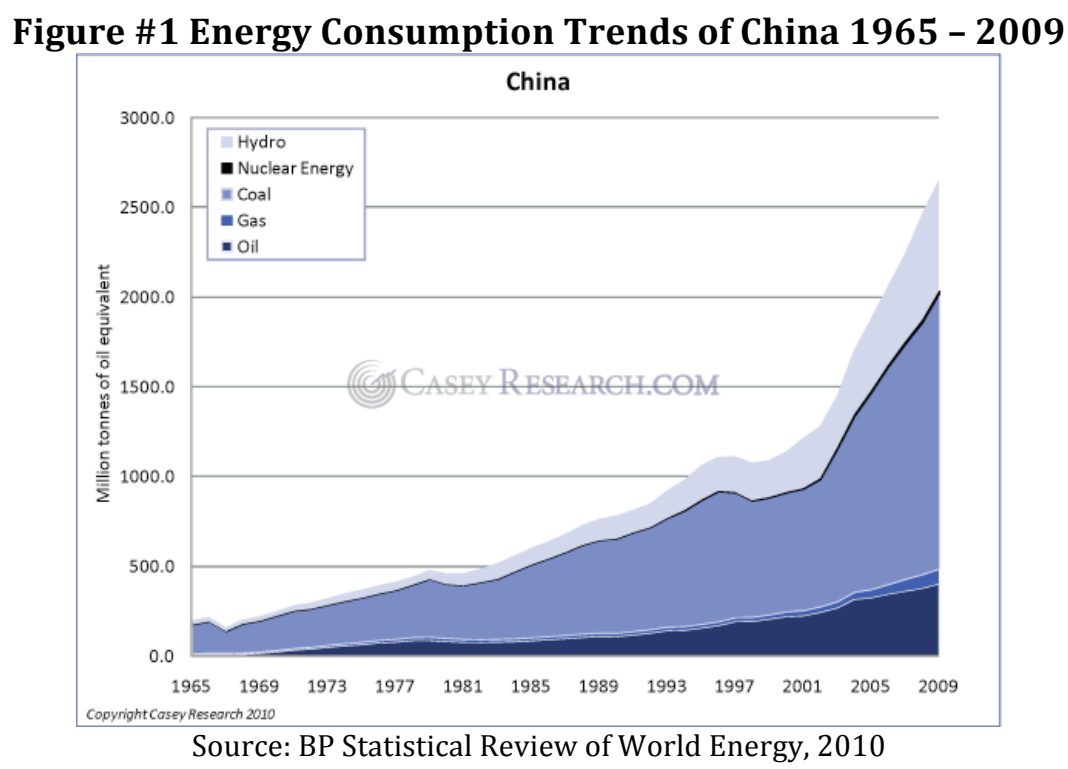

Back in 1999, it generated more than it consumed. The United States energy consumption relies mostly on oil (37\%), gas (25\%) and coal (21\%) with nuclear power accounting for $9 \%$ and renewable energy representing 8\% (see Figure \#2) (Ball, 2011).

Figure \#2 Energy Consumption Trends of the United States 1965 - 2009

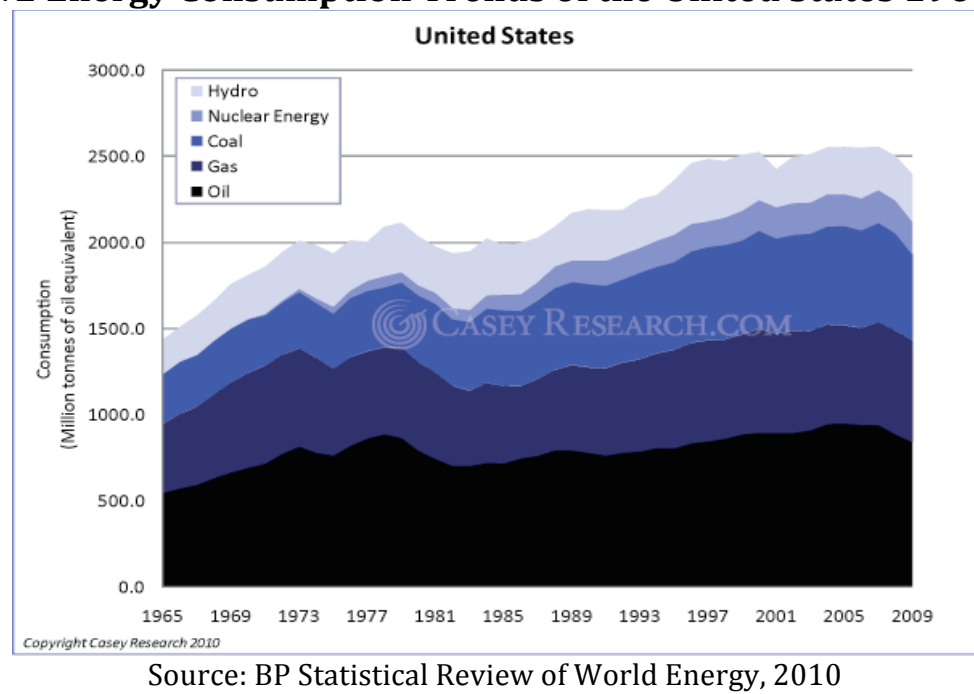


India relies on geothermal energy for the $80 \%$ of its energy, similar to the United States (see Figure \#3).

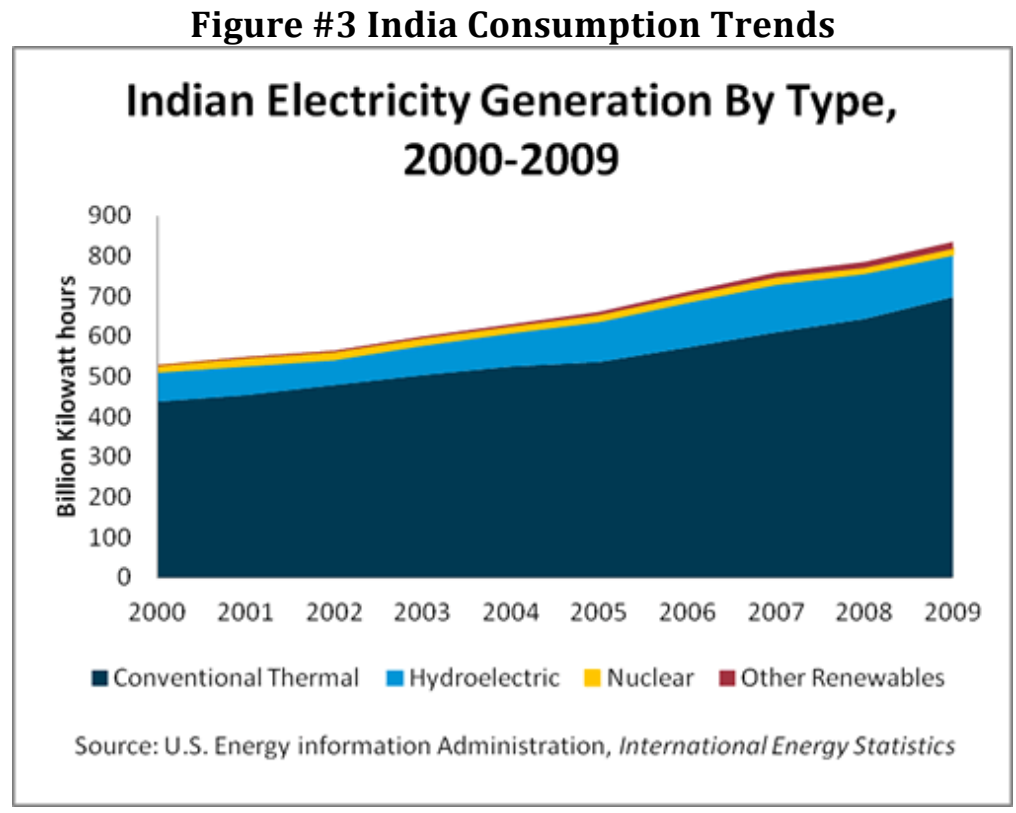

Source: Energy Information Administration, 2011.

Recently, according to a study by Chen et al. (2011:2014)" the movement of 2,000 animals and plants over the past decade away from the equator, from increasing heat, is three times faster than expected. In particular, the distributions of many terrestrial organisms are currently shifting in latitude or elevation in response to changing climate. Using a meta-analysis, we estimated that the distributions of species have recently shifted to higher elevations at a median rate of 11.0 meters per decade, and to higher latitudes at a median rate of 16.9 kilometers per decade. These rates are approximately two and three times faster than previously reported. The distances moved by species are greatest in studies showing the highest levels of warming, with average latitudinal shifts being generally sufficient to track temperature changes. However, individual species vary greatly in their rates of change, suggesting that the range shift of each species depends on multiple internal species traits and external drivers of change. Rapid average shifts derive from a wide diversity of responses by individual species." Another disturbing event associated with climate change is the severe decline in the numbers of migrating monarch butterflies. Last year there was an all-time low of approximately 60 million (Robbins, 2013). This year, estimates suggest that perhaps 35 million monarch butterflies have migrated to Mexico (Wines, 2014a:A16). Insects including honey bees stich together the web of life with essential services, breaking plants down into organic matter, dispersing seeds, and pollinating crops (Robbins, 2014).

\section{CLIMATE CHANGE AND WATER RESOURCES}

Water resources are critical for long-term sustainability of a country and region. It serves to critically provide daily personal and food needs of its people. According to the Ministry of Water Resources (MWR). China has two of the world's longest rivers, the Yangtze and the Yellow, with water reserves totaling 2.81 trillion cubic meters, making it the fifth richest in the world after Brazil, Russia, Canada and the United States. China supports $21 \%$ of the world's population with only $7 \%$ of the world's water. The country's per capita share of water is less than 2,200 cubic meters, only one-quarter of the global average (MWR). Also, the amount of water wasted in industrial production in China is quite high. In 2004, for every 10,000 yuan $(\$ 1,538$ approximately) in value-added industrial output, China used 196 cubic meters of water, while that figure in advanced countries was less than 50 cubic meters. Water recycling 
in industrial production was just $60-65 \%$ in China, compared with $80-85 \%$ in advanced countries $(\mathrm{Wu}, 2007)$. After 100 days without precipitation in Henan and six other provinces in the northern and central region of China, the central government declared a "Level 1" emergency. This lack of rainfall caused the worst drought in 50 years with $300 \mathrm{~m}$ yuan $(\$ 50$ million) extra being committed to drought-relief (Economist, 2009). Furthermore, this northern region grows three-fifths of China's crops and houses two-fifths of the population (Wines, 2009). Please see Table 1:

Table 1: Comparative Selected Aggregate Data from China, India, and U.S.

\begin{tabular}{|l|l|l|l|}
\hline & \multicolumn{1}{|c|}{ China } & \multicolumn{1}{c|}{ India } & \multicolumn{1}{c|}{ United States } \\
\hline Size & $\begin{array}{l}\text { total: } 9,596,960 \mathrm{sq} \mathrm{km} \\
\text { land: } 9,326,410 \mathrm{sq} \mathrm{km} \\
\text { water: } 270,550 \mathrm{sq} \mathrm{km}\end{array}$ & $\begin{array}{l}\text { total: } 3,287,590 \mathrm{sq} \mathrm{km} \\
\text { land: } 2,973,190 \mathrm{sq} \mathrm{km} \\
\text { water: } 314,400 \mathrm{sq} \mathrm{km}\end{array}$ & $\begin{array}{l}\text { total: } 9,631,418 \mathrm{sq} \mathrm{km} \\
\text { land: } 9,161,923 \mathrm{sq} \mathrm{km} \\
\text { water: } 469,495 \mathrm{sq} \mathrm{km} \\
\text { (note: includes only the } 50 \\
\text { states and District of } \\
\text { Columbia) }\end{array}$ \\
\hline Population: & $\begin{array}{l}1,343,239,923 \\
\text { (July 2012 est.) }\end{array}$ & $\begin{array}{l}313,847,465 \\
\text { (July 2012 est.) }\end{array}$ \\
\hline GINI Index & $48(2009)$ & $36.4(2006)$ & $45(2007)$ \\
\hline $\begin{array}{l}\text { Water Poverty Index } \\
\text { Ranking (WPI): }\end{array}$ & $103^{\text {rd }}$ & $97^{\text {th }}$ & $32^{\text {nd }}$ \\
\hline $\begin{array}{l}\text { Falkenmark Index: } \\
\text { (kcm) }\end{array}$ & $\begin{array}{l}2.2 \text { (thousands of cubic } \\
\text { meters of water per } \\
\text { capita }\end{array}$ & $1.9 \mathrm{kcm}$ & $8.9 \mathrm{kcm}$ \\
\hline
\end{tabular}

Even though China and the United States are of similar physical size, the U.S. population is $22.6 \%$ of China's. More critically, the U.S has almost twice the amount of water. Measured on a per capita basis, there is .000207 square kilometers (sq. km.) versus .001587 sq. km. of water in China and the U.S., respectively approximately 13\%. Admittedly, this is a rough measure of availability since the water is measured by surface area and not on a cubic meter basis. Arguably, an improvement on this was a study by Lawrence et al. (2002) that yields an index called the Water Poverty Index (WPI). On this WPI list the U.S. is ranked 32nd, India is $97^{\text {th }}$, and China is $103^{\text {rd }}$. A component of the WPI, the Falkenmark water stress index measures per capita water availability and considers that a per capita water availability measured by thousands of cubic meters per capita ( $\mathrm{kcm}$ ) (Falkenmark \& Widstrand, 1992). The Falkenmark index in 2002 was $8.9 \mathrm{kcm}$ for the U.S., $1.9 \mathrm{kcm}$ for India, and $2.2 \mathrm{kcm}$ for China (please see Table 2). India (13\%), China (12\%) and the USA (9\%) are the largest consumers of the global water resources (Hoekstra \& Chapagain, 2006). 
Table 2: C02 Emissions by Selected Country.

\begin{tabular}{|c|l|c|l|}
\hline Rank & Amount (per 1000 people) & Rank & Amount (per 1000 people) \\
\hline 1 & Qatar: 40.6735 & 34 & Norway:7.68826 \\
\hline 5 & United States:19.4839 & 35 & Italy:7.68629 \\
\hline 6 & Luxembourg:17.977 & 36 & Spain:7.55763 \\
\hline 8 & Australia:16.5444 & 37 & Iceland:7.5208 \\
\hline 9 & Canada:15.8941 & 44 & Portugal:6.1342 \\
\hline 12 & Belgium:12.0632 & 46 & France:5.99255 \\
\hline 15 & Finland:10.8403 & 50 & Switzerland:5.5801 \\
\hline 16 & Russia:10.7402 & 51 & Sweden:5.41667 \\
\hline 17 & Ireland:10.6612 & 66 & Mexico:3.62584 \\
\hline 18 & Netherlands:10.6545 & 67 & Argentina:3.51517 \\
\hline 20 & Germany:10.1591 & 68 & Chile:3.42842 \\
\hline 22 & Israel:9.99186 & 71 & Turkey:3.21359 \\
\hline 23 & Japan:9.61204 & 80 & China:2.65908 \\
\hline 24 & Denmark:9.44788 & 90 & Panama:1.81812 \\
\hline 25 & United Kingdom:9.23587 & 91 & Brazil:1.76161 \\
\hline 27 & Greece:8.63801 & 113 & India:0.933086 \\
\hline 30 & New Zealand:8.08758 & 176 & Congo, The Democratic \\
& & & Republic of:0.0123428 \\
\hline 31 & Poland:7.87846 & & \\
\hline 32 & 32 Austria:7.8658 & & \\
\hline $\begin{array}{l}\text { Definition: CO2: Total Emissions (excluding land-use) Units: thousand metric tons of carbon dioxide. } \\
\text { Source: World Resources Institute. 2003. Carbon Emissions from energy use and cement } \\
\text { manufacturing, 1850 to 2000. Available on-line through the Climate Analysis Indicators Tool (CAIT) } \\
\text { at Washington, DC: World Resources Institute via Nation Master. }\end{array}$ \\
\hline
\end{tabular}

Climate change will impact water supplies, exacerbating existing pressures on water resources caused by population and economic growth. Given the combination of these stressors, the sustainability of water resources in future decades is a concern in many parts of the world. Groundwater depletion is not limited to dry climates: pollution and mismanagement of surface waters can cause over-reliance on groundwater in regions where annual rainfall is abundant (Rodell et al., 2009)“ Many challenges, including climate change, face the Nation's water managers. The Intergovernmental Panel on Climate Change (IPCC) has provided estimates of how climate may change, but more understanding of the processes driving the changes, the sequences of the changes, and the manifestation of these global changes at different scales could be beneficial. Since the changes will likely affect fundamental drivers of the hydrological cycle, climate change may have a large impact on water resources and water resources managers" (Brekke et al., 2009).

As part of the analysis undertaken by Tetra Tech (Brekke et al., 2009), for the Natural Resources Defense Council (2010), a water supply sustainability index composed of five attributes of water use and growth was developed, and used to compare impacts across regions. Those factors are:

1) Projected water demand as a share of available precipitation;

2) Groundwater us as a share of projected available precipitation;

3) Susceptibility to drought; 4) projected increase in freshwater withdrawals; and

5) Projected increase in summer water deficit.

Brekke et al. (2009) found that, "under the business-as-usual scenario of demand growth, water supplies in $70 \%$ of counties in the US may be at risk to climate change, and 
approximately one-third of counties may be at high or extreme risk. The geographic extent of potential risk to water supplies is greatly increased when climate change is considered (see Figure \#4).

Figure \#4 National Water Supply Sustainability Index

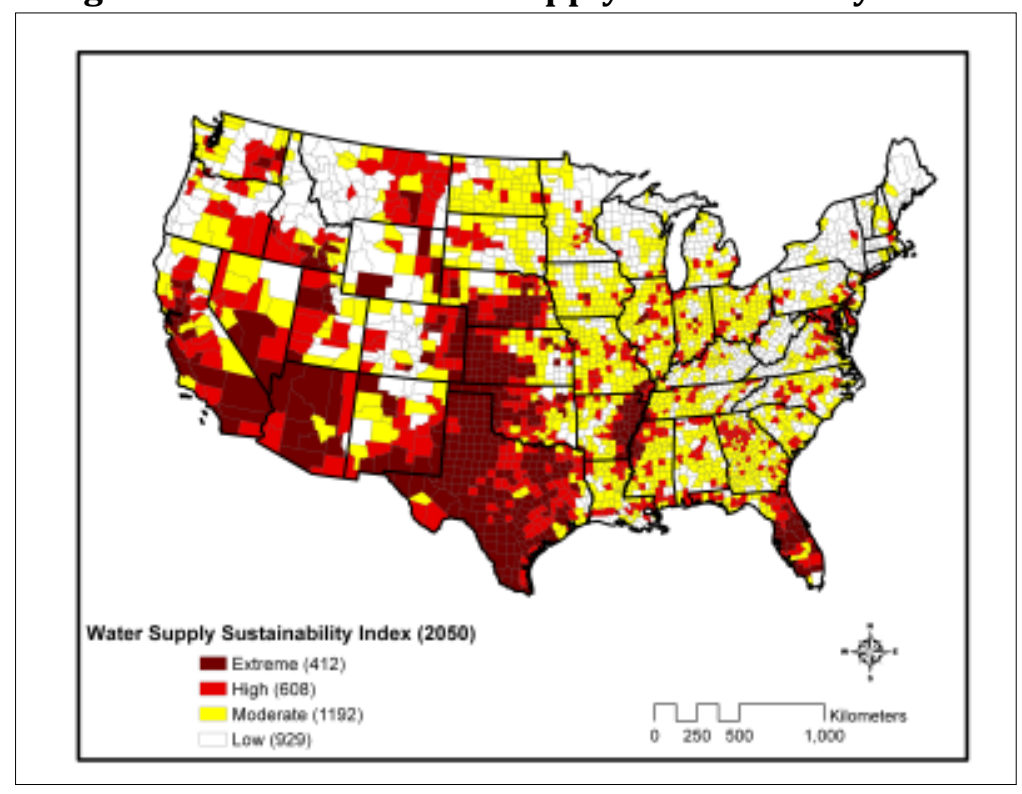

Source: Climate Change: Risks to U.S. Water Supplies Will Increase (2010)

This calculation indicates the increase in risk that affected counties face that water demand will outstrip supplies, if no other remedial actions are taken."

Another effect climate change has on water resources is the shrinking of sea ice at the north and south poles. Recently there is some evidence that there is a growth of sea ice in Antarctica driven by winds in a more exposed south pole (Hotz, 2012:A8) However, as the Arctic snow and ice melt, darker land and ocean surface open up and absorb more of the sun's energy. Therefore, the temperature increases faster - referred to as Arctic amplification. According to simulations conducted by the Intergovernmental Panel on Climate Change (IPCC) the Arctic will warm between 7 and 13 degrees Farenheit (F) over the next 100 years (Cullen, 2010:167171)

As sea levels rise, it may have some devastating effects on island nations, especially "in the Pacific, where the sea level is projected to rise three feet or more by the end of the century. Already, Nauru's coast, the only habitable area, is steadily eroding, and communities in Papua New Guinea and the Solomon Islands have been forced to flee their homes to escape record tides. The low-lying nations of Tuvalu, Kiribati, the Maldives and the Marshall Islands may vanish entirely within our grandchildren's lifetimes. In 2009, an initiative by the Pacific Small Island Developing States, prompted the United Nations General Assembly to recognize the link between climate change and security. But two years later, no concrete action has been taken" (Stephen, 2011). If the international community cannot or will not slow global warming, the least it can do is help those states prepare for life after land by recognizing a new category of state - the deterritorialized state (Rayfuse, 2011). Furthermore, recently we have seen the devastating effects of rising flood levels as a result of Hurricane Sandy that created an estimated $\$ 60$ billion of devastation to homes, office buildings, power stations, transportation systems (Klinenberg, 2013). 


\section{United States and Climate Policy}

The Obama administration has said that United States is committed to reduce their energy consumption by $17 \%$ by 2020 (Boder, 2010). For example, proposals for the first large solar plants ever built in on federal lands won final approval on October $6^{\text {th }}$, 2010. It reflects the Obama administration's commitment to promote renewable energy. Two solar plants will be built in Imperial and Lucerne Valleys in California - 754 megawatts will eventually be generated by these two plants (Barringer, 2010). On another front, the U.S. military has taken the initiative to decrease its dependence on fossil fuels, and switching to renewable sources of energy. For example, the Air Force has been testing a 50-50 mix of plant based bio-fuels and jet fuels. Further they have targeted 2011 as when the entire fleet will fly on bio-fuels (Rosenthal, 2010).

The Obama administration hopes to achieve energy savings of up to $\$ 2$ billion per year, as well as a reduction in emissions of carbon dioxide and other gases blamed for global warming. According to the congressional officials, the presidential orders will require vehicle manufacturers to speed efforts to make and sell cars and trucks that get higher mileage than the national standard. President Obama also will direct the Department of Transportation to begin drafting automobile fuel-economy regulations to comply with a law enacted in December 2007 according to the Alternative Fuels Data Center. President Bush delayed implementing the law and left office saying there was not sufficient time to write the rules. However, the EPA'a January 2010 proposal, to tighten air-quality standard below those of George W. Bush and even further below what most states adhere to was withdrawn by President Obama as he bowed to industry and Republican pressures citing the importance of "reducing regulatory burdens and regulatory uncertainty, particularly as our economy continues to recover" (Solomon \& Tracy, 2011:B5).

However, the complexity of the process involves legislation, regulation, and research and development. Recognizing this fact, a joint proposal by the conservative American Enterprise Institute (AEI) and the liberal Brookings Institute calls for the U.S. government to increase federal spending on clean energy from $\$ 4$ billion to $\$ 25$ billion a year (Leondardt, 2010). To put this amount in context, the National Institute of Health $(\mathrm{NIH})$ receives $\$ 36$ billion a year. The proposal also suggests a cap and trade program, charging about one third of what the defunct Senate bill would have charged to raise some of the $\$ 25$ billion (Leonhardt, 2010). The United States ranks the highest among developed countries at $5^{\text {th }}$ in the world in carbon emissions per capita (please see Table 2).

\section{China and Climate Change}

A joint report by the World Bank and the State Environmental Protection Administration, the Peoples Republic of China, pollution in China has either directly or indirectly caused the death of as many as 750,000 people a year (World Bank and the State Environmental Protection Administration, 2007). In India, it is estimated that one-eighth of its premature deaths are caused by air pollution and several hundred of thousand children die every year from polluted water (Luce, 2007: 343). Furthermore, it has been argued that 80 percent of surface water in China and 75 percent in India are polluted beyond use (Royte, 2008). Globally, the availability of freshwater is steadily decreasing, and that trend is expected to continue as the world's population grows to nine billion, emerging economies increase consumption levels, and climate change continues (WBSCD, 2008). Now, we are able to talk about our "water footprint" just as we talk about our "carbon footprint" (Gertner, 2007). Seven global groups, including the World Business Council for Sustainable Development (WBCSD), setup the Water Footprint Network, with the aim of working towards a common approach to water footprint measurement, accounting and reporting (WBCSD, 2008). 
An interesting construct is the water footprint indicating water consumption per capita. Specifically, the four major direct factors determining the water footprint of a country are: volume of consumption (related to gross national product); consumption patterns (e.g., high versus low meat consumption); climate (growth conditions); and, agriculture practices (water use efficiency). The global average water footprint is $1240 \mathrm{~m} 3 /$ per capita/per year. However, the differences in the global water footprint among countries are large. For example, the USA has an average water footprint of $2480 \mathrm{~m} 3 /$ capita/year whereas China has an average water footprint of 700m3/capita/year (Hoekstra \& Chapagain, 2006).

Sustainable development is critical to China for the two most significant regions of economic development in China, the Pearl and Yangtze River Deltas. China's economy has been growing at $8-10 \%$ for more than a decade. However, China's trade surplus narrowed in August of 2010 as imports picked up at a faster pace and exports slowed although not drastically. "The General Administration of Customs said exports were up 34.4\% in August 2010 compared to the same month a year ago, slowing from July's 38.1\% rise. Imports jumped 35.2\%, faster than the $22.7 \%$ increase in July. China's trade surplus dropped to $\$ 20$ billion in August from an 18month high of $\$ 28.7$ billion in the previous month. In the January to August period, exports increased $35.5 \%$ from the same period a year ago, while imports rose $45.5 \%$. A cumulative trade surplus of $\$ 103.9$ billion was registered" (TradingEconomics.com, 2010). However, critically, air and water quality in Chinese cities are worsening. According to a survey by the Environmental Protection Administration, 38\% of 585 cities enjoyed air quality that reached minimal national standards, down from 45\% in a 2005 survey (French, 2007:A6).

Arguably, the Olympics Games in 2008 made a start at recasting China, usually identified as an extreme environmental polluter, in a new eco-light. Beijing invested some US\$12 billion in environmental projects between 2001, when it won the bid to host the Olympics, and 2008. Dozens of polluting factories were relocated from the city to its outskirts and forest cover increased by several times, thanks in part to a 680-hectare Olympic Forest Park, the largest public green space in the country (Aiyar, 2010).

Bradsher (2007) identifies the dilemma of increasing energy needs for development and the resulting pollution, especially in the villages of India and inner China. Alternative energy sources are being sought in both countries to satisfy increasing demand. For example, farmers in China are using cheap rooftop solar water heaters. However, the heaters need to be installed on flat concrete roofs that are less prevalent than the sloped tile roofs. Further, it was reported that China planed on deriving $10 \%$ of its electricity from renewable sources, not counting hydroelectric projects, by 2010 (Wald, 2007:C7). Perhaps unrealistically, meeting that goal of six gigawatts of electricity would require a two year output from all solar panel makers in the world. In India and China, biomass furnaces are being used to supplement the use of more polluting diesel and coal generators, respectively. In 2008, leaders of the G8 group of nations called for the development of 20 large-scale projects demonstrating technologies for carbon capture and storage (CCS) by 2010, but countries have been slow to embrace the costly plants (Tollofson \& Van Noorden, 2012). China, in particular, announced that they plannned to open the most high-tech coal fired plant in the world in 2011, so-called Green-Gen (Osnos, 2009). Although it was a year later, in the Spring of 2012, China opened it first Green-Gen coal plant that captures its carbon dioxide in Tianjin by China's state-owned Huaneng Group with Peabody Energy of St Louis, Missouri (Tollofson \& Van Noorden, 2012).

China is emerging as the surprise leader in green technologies. The country's vast market and economies of scale are bringing down the cost of solar and wind energy; the "China price"-the 
combination of cheap labor and capital that revolutionized global manufacturing-is being replicated in clean technologies. China has emerged as one of the world's largest makers of wind turbines in the matter of a few years, and the country has a 30 percent share of the global market for photovoltaic solar panels used to generate electricity (Aiyar, 2010).

"The Chinese government is considering plans to subsidize the use of energy-efficient materials and renewable energy technologies in new buildings and is encouraging provincial and municipal governments to impose stricter efficiency standards than the national minimums. With 13 million to 21 million rural people in China migrating to cities each year a number comparable to the 18.9 million people in metropolitan New York - the real estate industry has been putting up office towers and apartment buildings at a brisk pace but often with little regard for energy efficiency" (Bradsher, 2011).

Further, as Bradsher (2011) pointed out, the Chinese government has been holding down electricity prices as an anti-inflation measure even as spot prices for coal, the country's dominant fuel for power generation, have doubled in the last five years. Chinese electricity companies have responded by limiting the operating hours of coal-fired plants in the last two years and slowing construction of new power plants, causing blackouts that have focused more public attention on the energy efficiency of buildings. Residential electricity rates in China are half to two-thirds of rates in the United States. Industrial electricity rates in China are officially higher than those in the United States.

\section{India and Climate Change}

India, the second-biggest producer of rice, wheat and sugar, is the most vulnerable among the world's leading industrial and emerging economies to future water stress, according to HSBC. India exhibits the most worrying trends among the Group of 20 nations with the resource "hovering dangerously near extreme scarcity levels" by 2030, HSBC said in a report today that forecast the group's water consumption against supply (Sunday Morning Herald, 2012).

India exhibits the most worrying trends among the Group of 20 nations with the resource "hovering dangerously near extreme scarcity levels" by 2030, HSBC said in a report today that forecast the group's water consumption against supply. The worst U.S. drought in a halfcentury drove corn and soybeans to records in August. Agriculture is the biggest consumer of water and India, the most dependent on farming among the G-20 nations, uses 25 percent of all water consumed globally by the industry, HSBC found.

Companies are unlikely today to disclose information on local water scarcity that can affect farms, plants and operations, it said. Investors will increasingly demand more disclosure to assess potential disruption to earnings. According to United Nation definitions, India is already officially water-stressed while Saudi Arabia, South Africa and South Korea are water-scarce. Historical trends are no longer a reliable way to assess future availability as climate change affects rain patterns and glacial melt, it said. Changing water patterns have already forced the closure of power, oil and gas and textile facilities in India this year (Sunday Moring Herald, 2012).

\section{United States}

\section{THE DEPLETION OF AQUIFERS}

"America is, on average, a damp nation -- the lower 48 states see 4,200 billion gallons of rainfall every day. But averages deceive; water is in short supply in the Southwest, where growth is fastest and rivers are already over-tapped. The Ipswich River near Boston now "runs dry about every other year or so," according to Sandra Postel, director of the Global Water Policy Project. 
"Why? Heavy pumping of groundwater for irrigation of big green lawns." In drought years like 1999 or 2003, Maryland, Virginia and the District have begun to fight over the Potomac - on hot summer days combining to suck up 85 percent of the river's flow" (Washington Post, 2006).

A report by the National Academies on the Colorado River basin had concluded that the combination of limited Colorado River water supplies, increasing demands, warmer temperatures and the prospect of recurrent droughts "point to a future in which the potential for conflict" among those who use the river will be ever-present. Over the past few decades, the driest states in the United States have become some of the fastest growing; meanwhile, an ongoing drought has brought the flow of the Colorado to its lowest levels since measurements at Lee's Ferry began 85 years ago. At the Senate hearing, Udall stated that the Colorado River basin is already two degrees warmer than it was in 1976 and that it is foolhardy to imagine that the next 50 years will resemble the last 50. Lake Mead, the enormous reservoir in Arizona and Nevada that supplies nearly all the water for Las Vegas, is half-empty, and statistical models indicate that it will never be full again (Gertner, 2007). Lake Mead dropped to its lowest point since it was first filled in the 1930s (Barringer \& Henriques, 2010). After 14 years of drought, nearly unrivaled in 1,250 years, federal authorities will for the first time decrease the amount of water that flows into Lake Mead from Lake Powell 180 miles upstream. Furthermore, if Lake Mead drops below 1,000 feet above sea level, millions of people will lose their source of water (Wines, 2014b: A1) (please see Figure \#5).

\section{Figure \#5}

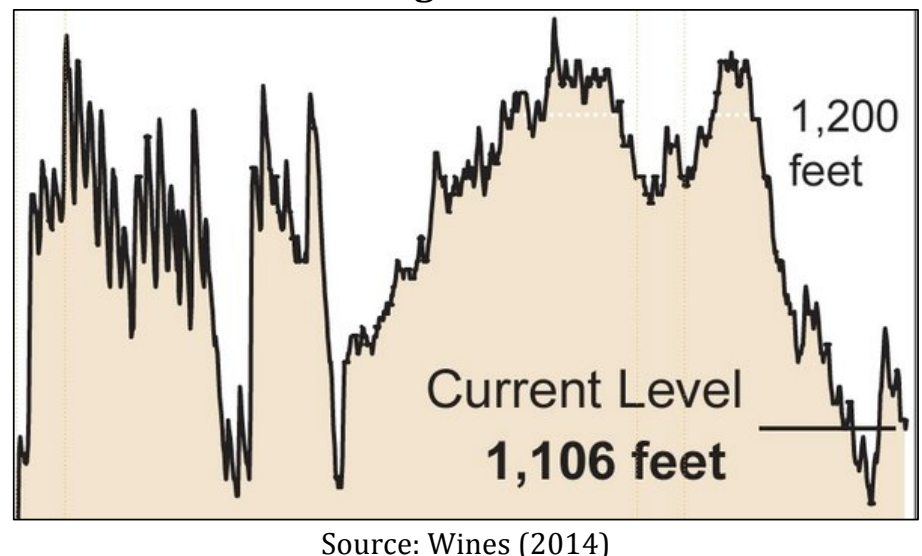

Studies of tree rings in the United States, core samples from the oldest Ponderosa pines or Douglas firs used to determine moisture levels hundreds of years ago, indicate that the dry times of the 1950s were mild and brief compared with other historical droughts. The latest research effort, published in the journal Geophysical Research Letters in late May 2007, identified the existence of an epochal Southwestern mega-drought that, if it recurred, would prove calamitous (Gertner, 2007).

\section{China}

A century or so ago, the North China Plain was a healthy ecosystem, scientists say. Farmers digging wells could strike water within eight feet. Streams and creeks meandered through the region. Swamps, natural springs and wetlands were common. Today, the region, comparable in size to New Mexico, is parched. Roughly five-sixths of the wetlands have dried up, according to one study. Scientists say that most natural streams or creeks have disappeared. Several rivers that once were navigable are now mostly dust and brush. The largest natural freshwater lake in northern China, Lake Baiyangdian, is steadily contracting and besieged with pollution. 
The causes includes misguided policies, unintended consequences, a population explosion, climate change and, most of all, relentless economic growth. In 1963, a flood paralyzed the region, prompting Mao to construct a flood-control system of dams, reservoirs and concrete spillways. Flood control improved but the ecological balance was altered as the dams began choking off rivers that once flowed eastward into the North China Plain.

The new reservoirs gradually became major water suppliers for growing cities like Shijiazhuang. Farmers, the region's biggest water users, began depending almost exclusively on wells. Rainfall steadily declined in what some scientists now believe is a consequence of climate change. Before, farmers had compensated for the region's limited annual rainfall by planting only three crops every two years. But underground water seemed limitless and government policies pushed for higher production, so farmers began planting a second annual crop, usually winter wheat, which requires a lot of water. Around 1900, Shijiazhuang was a collection of farming villages. By 1950, the population had reached 335,000. This year, the city has roughly 2.3 million people with a metropolitan area population of 9 million.

"More people meant more demand for water, and the city now heavily pumps groundwater. The water table is falling more than a meter a year. Today, some city wells must descend more than 600 feet to reach clean water. In the deepest drilling areas, steep downward funnels have formed in the water table that are known as "cones of depression" (Yardley, 2007). Similarly, the water table in India has dropped from just 40 feet in 1960 to more than 600 feet in the early $21^{\text {st }}$ century (Luce, 2007:85).

The North China Plain undoubtedly needs any water it can get. An economic powerhouse with more than 200 million people, it has limited rainfall and depends on groundwater for 60 percent of its supply. Other countries, like Yemen, India, Mexico and the United States, have aquifers that are being drained to dangerously low levels. But scientists say those below the North China Plain may be drained within 30 years.

"There's no uncertainty," said Richard Evans, a hydrologist who has worked in China for two decades and has served as a consultant to the World Bank and China's Ministry of Water Resources (MWR). "The rate of decline is very clear, very well documented. They will run out of groundwater if the current rate continues" (Yardley, 2007). "The problems are the result of both scarcity and pollution. Many parts of the north and north-east - home to more than $500 \mathrm{~m}$ people - face persistent and sometimes severe water shortages. Three of the country's main industrial cities - Shanghai, Beijing and Tianjin - all have fewer per capita freshwater resources than Israel or Jordan" (Dyer, 2007).

In the past, the Communist Party has often turned to engineering projects to address water problems, and now it is reaching back to one of Mao's unrealized plans: the $\$ 62$ billion Southto-North Water Transfer Project to funnel more than 12 trillion gallons northward every year along three routes from the Yangtze River basin, where water is more abundant. The project is projected to be built in 2050. The eastern and central lines are already under construction; the western line, the most disputed because of environmental concerns, remains in the planning stages (Yardley, 2007).

\section{India}

The nation's average annual rainfall is extremely abundant by global standards, yet much of this rain falls in relatively brief deluges during the monsoon and there is great disparity across different regions. The combination of these climatic conditions with a range of man-made pressures has driven India's farmers, households, and industry to increasingly depend on 
groundwater rather than surface water in rivers and lakes. But this dependence is leading to a rapid and very worrying deterioration in the nation's groundwater resources (Wyrwoll, 2012). During the period of August 2002 to October 2008, groundwater depletion was equivalent to a net loss of $109 \mathrm{~km} 3$ of water, which is the double the capacity of India's largest surface water reservoir (Rodell et al., 2009).

India's declining groundwater resources are the product of a number of drivers. Utilization of groundwater facilitates irrigated agriculture in areas far from rivers; in fact, this was key to the agricultural "green revolution" that occurred from the mid 1960s. In places where surface water is available but unsafe for drinking or farming-more than $70 \%$ of India's surface water resources are polluted by human waste or toxic chemicals-groundwater has often been seen as a safe alternative. Urban water supply infrastructure is often poor and unreliable: well drilling is typically the most economical means of obtaining household water. In Delhi, the local government estimates that $40 \%$ of the water transmitted through the mains system is lost through leakages; for many, the only other alternative to bores are expensive supplies purchased from water-trucks (Wyrwoll, 2012).

In rural areas, electricity subsidies allowing farmers to pump groundwater cheaply have become entrenched in the political landscape. They are likely to become even more so as energy requirements increase to extract water from greater depths. Low cost encourages excess water withdrawal, an inefficient usage pattern commonly exacerbated by ineffective application methods and the wastage of agricultural produce between farm and market. In order to feed a growing and wealthier population, it is projected that agricultural water demand in the India of 2030 would need double to 1,200 billion $\mathrm{m}^{3}$ if these inefficient practices continued. The problems are only going to get worse unless urgent changes occur (Wyrwoll,2012).

\section{RECOMMENDATIONS TO SLOW CLIMATE CHANGE}

IBM has arguably taken a leadership role in using technology to create a more sustainable urban environment in their "Smarter Cities" initiative (IBM, 2011). In particular, "as centers of business, culture and life, cities are logical places to integrate many of the Smarter Planet principles and innovations in public safety, transportation, water, building, social services and agencies. A new kind of solution, the IBM Intelligent Operations Center for Smarter Cities, synchronizes and analyzes efforts among sectors and agencies as they happen, giving decision makers consolidated information that helps them anticipate-rather than just react toproblems. By using these tested approaches, cities can manage growth and development in a sustainable way that minimizes disruptions and helps increase prosperity for everyone." Included in this comprehensive program are greater efficiencies in government, public safety, healthcare, energy, and traffic. These solutions were recently discussed as a means of reducing the debilitating effects on the power grid by isolating more vulnerable areas in developing smart grids (Klinenberg, 2012). In this article, Klaus Jacob of Columbia University identifies Singapore and Rotterdam (Netherlands) successful efforts of developing proactive solutions to the threats of major flooding. He argues that these solutions can be replicated in the northeastern United States shown to be vulnerable to the deluge brought by Hurricane Sandy (Klinenber, 2013:33-34). Regarding the water shortage in California, a water-cleaning technology is being used to desalinate water using solar panels to separate the salts, selenium and other metals from the water. The start-up called WaterFX is tapping billions of contaminated water that lies just below the ground in the Central Valley of California. The plant, located in Firebaugh, California, is able to purify water using half as much energy as conventional desalinization (Woody, 2014:B1 \& B3). 
Totty (2011) also provides a wide range of activities for a more sustainable city. He suggested that "urban populations around the world are expected to soar in the next 20 years, to five billion from more than three billion today. If the current rate of urbanization holds steady, cities will account for nearly three-quarters of the world's energy demand by 2030. Most of the increase will come in rapidly developing countries like China and India; China's cities alone will have to deliver water, housing, transportation and other services to 400 million additional urban dwellers by 2030" (Trotty, 2011:R4). Some of the recommendations by Totty (2011) include the use of micro wind turbines, pumped hydro storage and micro hydropower, pneumatic garbage collection, and green rooftops. Another proposed change by the China's National Development and Reform Commission is the use of a three-tiered pricing system for water usage where the top $5 \%$ of household users will pay three times the base rate, the second tier 1.5 times the base rate and the lowest tier ( $80 \%$ of urban households) will not be affected (Spegele \& Kazer, 2014:A6).

"Rooftops, which take up a fifth of urban surface area, can be used to support solar panels or wind turbines, but they're otherwise underutilized. Covering the tops of buildings with grasses, shrubs and other plants can deliver a host of benefits. Though often more costly than traditional coverings, green roofs can provide insulation and trim a building's heating and cooling needs. They absorb rainwater, reducing the load on storm-water systems, and filter what water does run off so it can be used for many domestic needs. They also filter air pollutants" (Totty, 2011, R5).

Solar panel installations in cities will greatly reduce reliance on fossil fuels for energy (although the most expensive, see Figure \#6). Especially with the projected continued reduction in the cost of solar cells (see Figure \#7).

Figure \#6

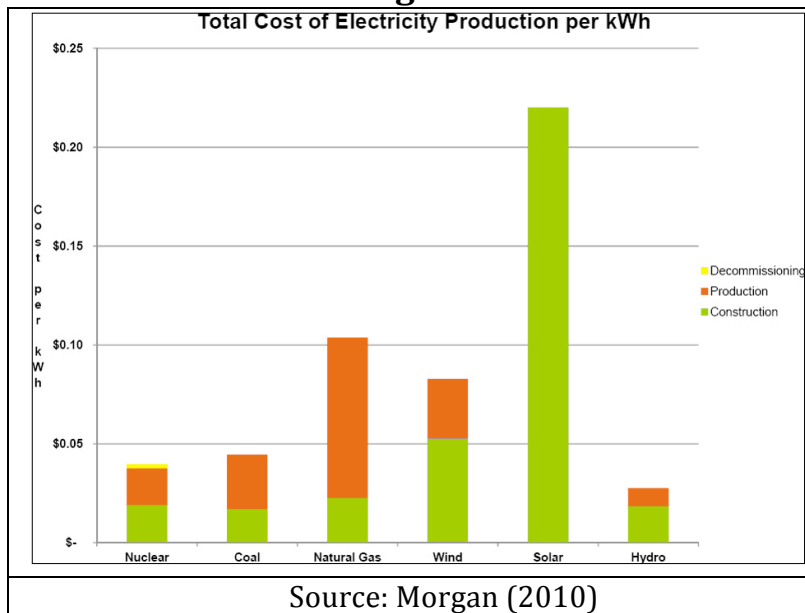

Figure \# 7 Projected Production of Solar Cells

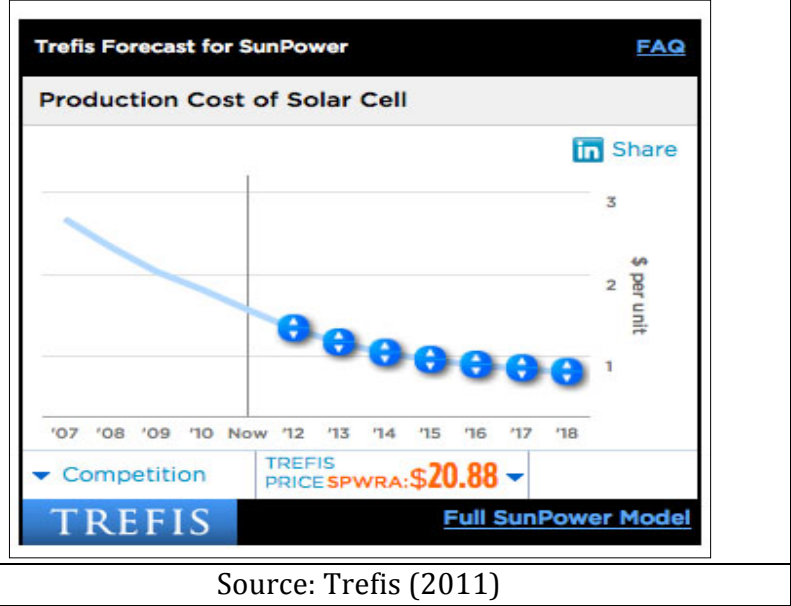

For example, "two-thirds of New York City's rooftops are suitable for solar panels and could jointly generate enough energy to meet half the city's demand for electricity at peak periods, according to a new, highly detailed interactive map. Specifically, 66.4 percent of the city's buildings have roof space suitable for solar panels, said the CUNY team, which developed the map in partnership with the city and the federal Department of Energy. The rooftops could generate up to 5,847 megawatts from hundreds of thousands of buildings, the team said, compared with the negligible 6.5 megawatts yielded now from about 400 installations. Nationwide, the installed solar capacity is just 2,300 megawatts, less than half the rooftop potential of New York City. In San Francisco, the number of solar installations on private roofs rose to more than 2,300 this year, from 551 in 2007, when the solar map was introduced along with financial incentives like tax credits and rebates" (Navarro, 2011). 


\section{CONCLUSION}

An Inuit elder in Igloolik (Canadian Arctic) described the weather as uggianaqtuq, meaning unexpected, unfamiliar, and/or unreasonable (Cullen, 2010: 154-5). Redoubling the efforts of many (or all) nations' efforts to prevent further climate change are essential. Also, it is critical for countries to cooperate in reducing global warming as well as increasing the efficiency of water usage although the meeting in Cancun (2010) did not result in any significant agreement among participating countries.

There are immense opportunities to reduce both consumptive and non-consumptive demand for water. These include installing more low-flow home appliances, adopting more efficient irrigation methods, "green architecture" such as agriculture on roofs in cities, and recycling of rainwater. Economic tools have also reduced consumption by making water more expensive, i.e. the more you use, the higher your per-gallon rate. The United States uses less water than it did 25 years ago (Gertner, 2007). Also, while desalination has been increasingly used in India, it is more than twice as expensive as waste water recycling. Europe recycles about $60 \%$ of the domestic sewage generated and it is consumed for non-potable applications such as boiler feed water, cooling tower, landscaping, gardening and flushing (Vijayakumar, 2012). Further, China has begun building desalination plants in Tianjin and east of Beijing. The desalination plant in Tianjin supplies 10,000 tons of desalted water per day. It plans to expand the production to 180,000 tons a day. The Beijing desalination project is expected to be completed by 2019 and to provide one million tons of fresh water per day which would account for one-third of Beijing's water needs for 22 million people (Wong, 2014:A8).

Furthermore, corporations are recognizing the economic costs of a changing climate. For example, Coca-Cola now uses water-conservation technologies after they lost a operating license in India because of a serious water shortage there in 2004. Nike, which has more than 700 factories in 49 countries, many in Southeast Asia, has faced shortages of cotton due to rising droughts. As a result, Nike is using more synthetic fibers that are less dependent on weather conditions (Davenport, 2014: A1 \& A19).

Recently, the Campbell Soup Company was named to the Global 100 Most Sustainable Corporations in the World list by the Corporate Knights recognized for its innovative energy and water conservation programs. Over the past four years, Campbell's capital investments in energy and water conservation have yielded a cumulative savings of more than $\$ 53.9$ million. Additional environmental stewardship achievements include: saving more than 1 billion gallons of water annually; reducing greenhouse gas emissions by more than 280,000 metric tons of CO2, the equivalent to emissions from nearly 60,000 cars; reducing waste sent to landfills by almost 7 percent and attaining an overall 85 percent recycle rate; and saving more than 2.4 million pounds of packaging through light weigh package redesign (Business Wire, 2014).

Since coal represents a significant portion of the China, India, and the United States energy, lower sulfur producing coals, such as bituminous, should be mined. Also, as mentioned earlier coal plants should be offered incentives to capture and bury carbon dioxide as was started at the American Electric Power plant in Mountaineer, West Virginia (Wald \& Broder, 2011: A1).

Water management is essential to lessen the depletion of water resources. However, arguably, it cannot be expected to counter the effects of a warming environment. Without radically reducing the use of fossil fuels, world temperatures may rise 2.4 to 6.4 degrees centigrade by 2100. If climate warming continues to increase, we can expect water shortages to increase with it. 


\section{References}

Aiyar, P. (2010). "From 2008 to 2010: Big-Ticket Spectacles in China and India." The Journal of Asian Studies, 69, No. 3: 683-685.

Alternative Fuels Data Center (http://www.afdc.energy.gov/laws/key_legislation)

Ball, J. (2011). “Wind Power hits a Trough.” Wall Street Journal, 5 April.

http://online.wsj.com/article/SB10001424052748704629104576190812458488694.html?KEYWORDS=jeffrey+ball

Barringer, F. (2010). “Solar Power Plants to Rise on U. S. Land.” New York Times, October 6: A16.

Barringer, F. \& Henriques, D.B. (2010). "Water Scarcity A Bond Risk, Study Warns.” New York Times, October 21: A1 \& A4.

Boder, J. M. (2010). “Poor Prospects for New Climate Meeting.” New York Times, October 8: A9.

Bradsher, K. (2011). “China Weighs Incentives To Aid Energy Efficiency.” New York Times, 16 June $2011:$ B4.

Bradsher, K. (2007). “CleanAir or TV: Paying in Pollution for Energy Hunger.” New York Times, 9 January: C1 \& C7.

Brekke, L.D., Kiang, J.E., Olsen, J.R., Pulwarty, R.S., Raff, D.A., Turnipseed, D.P., Webb, R.S., and White, K.D., 2009, Climate change and water resources management-A federal perspective: U.S. Geological Survey Circular 1331,65 p. ( http://pubs.usgs.gov/circ/1331/.)

Brown, L., Black, B., Hassan, G., \& Hussein, G. (2012) "Aquifer depletion," in Encyclopedia of Earth. Cleveland, C.J. (ed.) (Washington, D.C.: Environmental Information Coalition, National Council for Science and the Environment). [First published in the Encyclopedia of Earth January 23, 2010; Last revised Date May 3, 2012; Retrieved January 16, 2013.

Businee Wire (2014). "Campbell Soup Company Named to Global 100 Sustainability Index." http://online.wsj.com/article/PR-CO-20140122-907086.html

Chen, C., Hill, J.K., Ohlemüller, R., Roy, D.B., \& Thomas, C.D. “Rapid Range Shifts of Species Associated with High Levels of Climate Warming." Science, 333, \#6045, 19 August: 1024-1026.

Climate Change: Risks to U.S. Water Supplies Will Increase (2010). http://blog.nature.org/2010/07/climate-changewater-supply/

Davenport, C. (2014). “Industry Awakens to Threat of Climate Change.” New York Times, 24 January, A1 \& A19.

Dyer, G. (2007). "Business and Water: Pollution adds to a daunting resource shortage." Financial Times, 22 March. http://www.ft.com/cms/s/1/4b684464-d6e5-11db-98da-000b5df10621.html\#axzz1urEyxsdv

Cullen, H. (2010). The Weather of the Future: Heat Waves, Extreme Storms, and Other Scenes From a Climate Changes Planet. New York: Harper.

Energy Information Administration (2011). “Country Analysis Briefs: India.” 21 November. http://www.eia.gov/cabs/india/Full.html

Encyclopedia of Earth (2012). http://www.eoearth.org/article/Aquifer_depletion

Flynn, D. (2011). “Sustainable Development and Climate Change.” Proceedings, Pan-Pacific Conference XXVIII, Daejeon, Korea: 66-68.

French, H.W. (2007). “China: Cities Suffer More Pollution.” New York Times, 13 June: A6.

Gertner, J. (2007). "The Future is Drying Up.” New York Times Magazine, 21 October. http://www.nytimes.com/2007/10/21/magazine/21water-t.html?pagewanted=all\&_r=0

Gold, R. (2011). “Overrun by Chinese Rivals, U.S. Solar Company Falters.” Wall Street Journal, 17 August: B1 \& B4. Goodyear, D. (2011). “Grub: Eating Bugs to Save the Planet.” New Yorker, 15 \& 22 August: 38-46.

Hart, S.L. \& Milstein, M.B. (2003). “Creating Sustainable Value.” Academy of Management Executive, 17 (2): $56-69$. Hermanowicz, S.W. (2005). “Entropy and Energy: Toward a Definition of Physical Sustainability.” Working Paper, (http://repositories.cdlib.org/wrca/wp/swr v2). 
Hoekstra, A.Y. \& Chapagain, A.K. (2006). "Water footprints of nations: Water use by people as a function of their consumption pattern." Water Resources Management,(DOI 10.1007/s11269-006-9039-x).

Hotz, R.L. (2012). “Winds Drive Growth in Antarcic Sea Ice.” Wall Street Journal, 12 November: A8.

IBM (2011) www.ibm.com/smarterplanet/us/en/smarter_cities/overview/index.html

Klieneberg, E. (2013). “ADAPTATION: How can cities be “climate-proofed”?” New Yorker, 7 January: 32-37

Lant, C. (2004). “Water Resources Sustainability: An Ecological Economics Perspective.” Water Resources Update, 127: $20-30$.

Lawrence, P., Meigh, J., \& Sullivan, C. (2002). “The Water Poverty Index: an International Comparison.” Keele Economic Research Reports, 19.

Leonhardt, D. (2010). “Next Step On Policy For Climate.” New York Times, October 13: B1 \& B9.

Luce, E. (2007). In Spite of the Gods: The Strange Rise of Modern India. New York: Doubleday.

Morgan, J. (2010). “Comparing Energy Costs of Nuclear, Coal, Gas, Wind and Solar.”

http://nuclearfissionary.com/2010/04/02/comparing-energy-costs-of-nuclear-coal-gas-wind-and-solar/

Ministry of Water Resources (http://www.mwr.gov.cn/english/)

Natural Resources Defense Council (NRDC) (2010). “Climate Change, Water, and Risk: Current Water Demands Are Not Sustainable." July. (www.nrdc.org/global-warming/watersustainability/)

Navarro, M. (2011). “Interactive Map Shows, Rooftop by Rooftop, City’s Great Potential for Solar Power.” New York Times, 16 June 2011: A31.

New York Times (2010a). "Nagoya Has to Do Better" 20 October: A28

New York Times (2010b). “A Conditional Go-Ahead.” 13 October: A24.

New York Times (2010c). "Science Foundation Backs Climate-Change Play.” 4 October: C3.

Prager, S.C. (2011). “How Seawater Can Power the World.” New York Times, 11 July 2011: A19.

Osnos, E. (2009). “Green Giant: Beijing's crash program for clean energy.” New Yorker, 21 \& 28 December: 54-62.

Rayfuse, R. (2011). “Life After Land.” New York Times, 19 July: A23.

Robbins, J. (2013). “The Year the Monarch Didn't Appear.” New York Times, Sunday Review, 22 November.

Rodell, M., Velicogna, I. \& Famiglietti, J.S. (2009). “Satellite-based estimates of groundwater depletion in India.” Nature, 460, August: 999-1003.

Rosegrant, M.W. (1997). "Water Resources in the Twenty-First Century: Challenges and Implications for Action." Food, Agriculture, and the Environment Discussion Paper 20, 1-32.

Rosenthal, E. (2010). “Military Orders Less Dependence on Fossil Fuels.” New York Times, 5 October: A1 \& A13.

Royte, E. (2008). Bottlemania: How Water Went on Sale and Why We Bought It. Bloomsberry.

Solomon, D. \& Tracy, T. (2011). “Obama Asks EPA to Pull Ozone Rule.” Wall Street Journal, September 3-4: A5.

Spegele, B. \& Kazer, W. (2014). “To Conserve ater, China Raises Prices for Top Users.” Wall Street Journal, 4-5 January: A6.

State Grid Corporation of China (http://www.sgcc.com.cn/ywlm/gsgk-e/gsgk-e/gsgk-e1.shtm)

Stephen, M. (2011). “On Nauru, a Sinking Feeling.” New York Times, 19 July: A23.

Sunday Morning Herald (2012). “India most vulnerable to water shortages, report finds.” 20 September.

http://www.smh.com.au/environment/climate-change/india-most-vulnerable-to-water-shortages-report-finds-20120920267o9.html

Sunday Times Online (1/09/2009).

http://www.timesonline.co.uk/tol/news/environment/article5588346.ece 
Tollefson, J. \& Van Noorden, R. (2012). “Slow Progress to Cleaner Coal.” http://www.nature.com/news/slow-progressto-cleaner-coal-1.10411

Totty, M. (2011). “How to Build a Greener City.” Wall Street Journal, September 12: R4 \& R5.

Trefis (2011). "Suntech Stock Highly Sensitive to Production Cost of Solar Cells."

http://www.trefis.com/stock/stp/articles/44628/suntech-stock-highly-sensitive-to-production-cost-of-solar-cells/2011-0321

Vijayakumar, S. (2012). "Simple \& cheap solution to India's grave water crisis: Waste water recycling." Economic Times, September 23.

http://articles.economictimes.indiatimes.com/2012-09-23/news/34022987_1_desalination-plant-water-resources-wastewater

Wald, M.L. (2007). "Venture Capital Rushes Into Alternative Energy." New York Times, 30 April: C7.

Wald, M.L. \& Broder, J.M. (2011). Utility Shelves Ambitious Plan to Limit Carbon.” New York Times, 14 July: A1 \& A3.

Washington Post (2009). “Getting Resourceful About Resources.” 1 January. http:/www.washingtonpost.com/wpdyn/content/article/2005/12/31/AR2005123100307.html

Wines, M. (2014a). “Migration of Monarch Butterflies Shrinks Again Under Inhospitable Conditions.” New York Times, 30 January, A14.

Wines, M. (2014b). “Colorado River Forces A Painful Reckoning for States.” New York Times, 6 January: A1 \& A10.

Wines, M. (2009). "Worst Drought in Half Century Shrivels the Wheat Belt of China." New York Times, 25 February: A5 \& A8.

Wong, E. (2014). “Desalination Plant Said to Be Planned for Thirsty Beijing.” New York Times, 16 April: A8.

Woody, T. (2014). "Water-Cleaning Technology Could Help Farmers.” New York Times, 17 February, B1 \& B3.

World Bank and the State Environmental Protection Administration (2007). Cost of Pollution in China: Economic Effects of Physical Damage. March.

World Business Council for Sustainable Development (WBCSD) (2008). "Business Takes Lead on Water by Joining the Water Footprint Network." 16 October

(http://www.wbcsd.org/plugins/DocSearch/details.asp?type=DocDet\&ObjectId=MzIwNzk)

World Commission on Environment and Development (1987). Our Common Future. Oxford: Oxford University Press.

Wu, Zhong (2007). "Sun Wukong: China's going down the drain." 7 March.

http://www.atimes.com/atimes/China_Business/IC07Cb03.html

Wyrwoll, P. (2012). "India's Groundwater Crisis."

http://www.globalwaterforum.org/2012/07/30/indias-groundwater-crisis/

Yardley, J. (2007). “Under China's Booming North, the Future is drying up.” New York Times, 28 September:A1 \& A16. 